\title{
КОМПЛЕКСЫ ДИАТОМОВЫХ ВОДОРОСЛЕЙ ИЗ ОСАДКОВ ОЗЕРА ТРИДЦАТКА (КАРЕЛЬСКИЙ БЕРЕГ БЕЛОГО МОРЯ)
}

Косова А.Л. ${ }^{1}$, Денисов Д.Б. ${ }^{1}$, Николаева С.Б. ${ }^{2}$

${ }^{1}$ Институт проблем промышленной экологии Севера КНЦ РАН, Anamumbl,annkosova1976@yandex.ru

${ }^{2}$ Геологический институт КНЦ РАН, Anamumbl,nikolaeva@geoksc.apatity.ru

\section{Введение}

В настоящее время в вопросах исследования динамики природной среды широко используются различные биоиндикаторы, захороненные в осадках. Одним из видов таких биоиндикаторов являются диатомовые водоросли. Они широко распространены, хорошо сохраняются в осадках и способны быстро менять видовой состав и структуру экологических групп в ответ на изменение экологической обстановки.

\section{Материалы и методы}

Материалом для данной работы послужили результаты диатомового анализа донных отложений (ДО) озера Тридцатки (66 $\left.47^{\prime} 129^{\prime} ; 32^{\circ} 23^{\prime} 043^{\prime \prime}\right)$ с абсолютной отметкой уреза воды 49.6 м, расположенного в 11 км западнее Карельского берега Белого моря. Максимальная глубина озера 6.5 м,

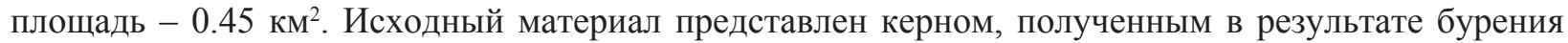
ДО в самом глубоком месте озера с помощью поршневого бура. С глубины 6.5 м были отобраны осадки мощностью 1 м. Диатомовый анализ ДО был проведен по стандартной общепринятой методике [2, 5], по схеме, используемой в ИППЭС КНЦ РАН [8], по 11 образцам с разными интервалами. Наиболее подробно изучены осадки с глубины 7.03-7.12 м. Нижняя часть разреза с глубины 7.50-7.12 м изучены с интервалом 10 см, верхняя часть с глубины 7.03-6.57 м изучены с интервалом 10-20 см. Определение всех обнаруженных в препаратах створок диатомовых водорослей, по возможности, до внутривидовых таксономических категорий, и их экологическая характеристика приведены согласно источникам [3, 4, 6, 7, 10, 11-14]. Номенклатуру приводили согласно международной альгологической базе данных [http://www.algaebase.org]. Подсчет и таксономическая идентификация диатомей осуществлялись с использованием светового микроскопа «Wild Leitz GMBH» (Туре 020-507.010) при увеличении в 1000 раз, с применением иммерсионного объектива. Радиоуглеродное датирование образца гиттии выполнено в лаборатории палеогеографии и геохронологии четвертичного периода факультета географии и геоэкологии СПбГУ в Санкт-Петербурге. Значения календарного возраста приведены на основании калибровочной программы «CalPal2007_HULU» Кёльнского университета 2007 года [www.calpal.de].

\section{Результаты и обсуждения}

Литологическое строение разреза донных отложений

В разрезе донных отложений, вскрытых при бурении, установлены следующие слои (номера слоев и их описание указаны сверху вниз от уреза воды):

(1) 6.50-7.08 м - гиттия темно-коричневая рыхлая, с шарообразными буровато-коричневыми включениями размером 0.1-0.15 см органического материала;

(2) 7.08-7.10 м - гиттия алевритистая слоистая с чередованием слойков темного и светлого цвета. Толщина слойков - от 0.3 до 0.9 см. Переход к вышележащему слою резкий, по светлому слойку.

(3) 7.10 - 7.38 м - алеврит опесчаненный от серого до светло-серого цвета с примесью песка, обогащенный ракушняковым детритом в виде тонких пластинок белого цвета. Переход к вышележащему слою резкий.

(4) 7.38 - 7.50 м - алеврит серого цвета с прослоями и линзами тонкозернистого песка, включениями зерен гравия и обломков пород диаметром до 3.5 см. Переход к вышележащему слою постепенный. 


\section{Диатомовый анализ}

Всего в изученных отложениях было обнаружено 103 вида в 37 родах. Значимые изменения видового состава и структуры диатомовых комплексов по разрезу позволили выделить 4 диатомовые зоны, которые подтверждаются результатами кластерного анализа, выполненного на основе соотношения относительной численности диатомей. На рисунке изображена динамика относительной численности массовых видов диатомовых водорослей.

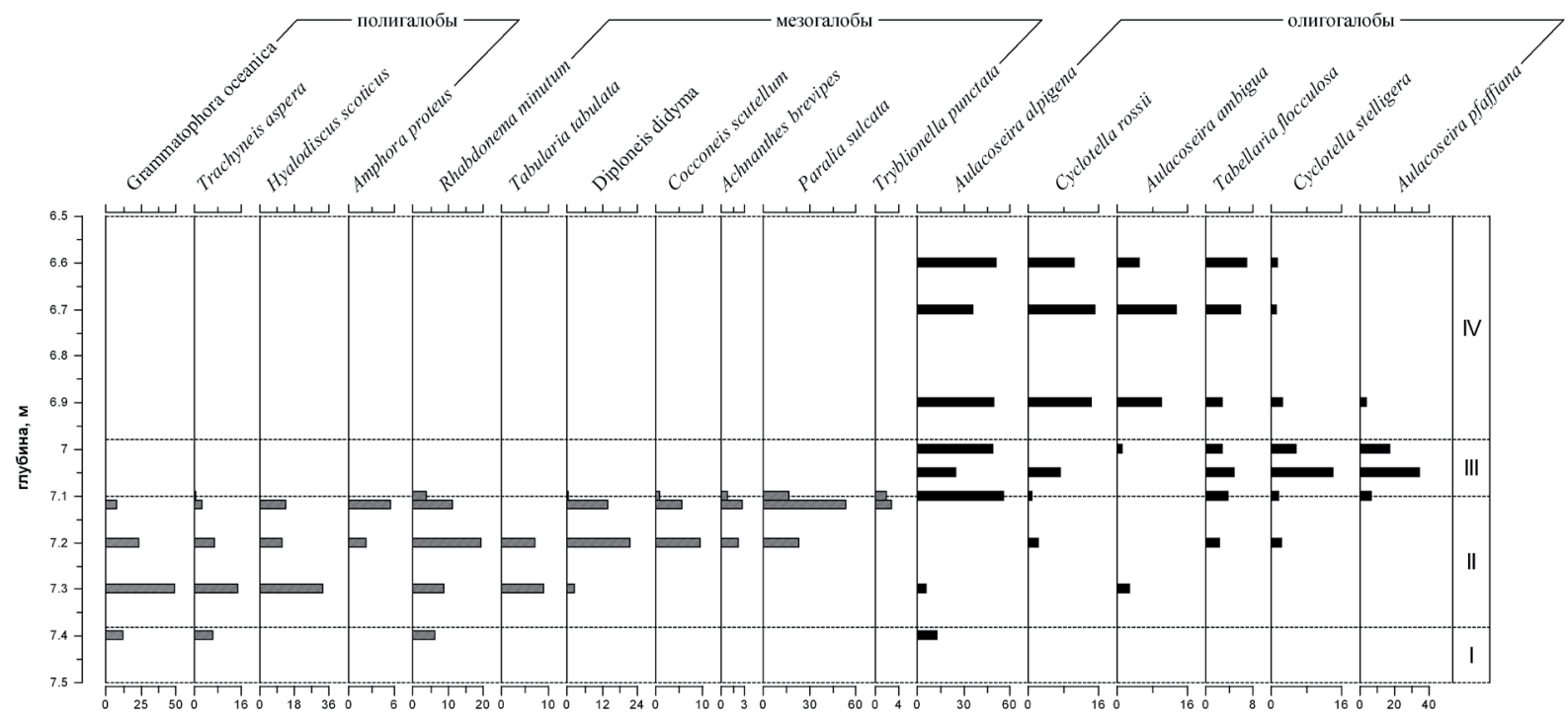

Диатомовая диаграмма массовых видов из донных отложений озера Тридцатка.

Зона I (интервал 7.38-7.50 м). В образце из данного интервала на глубине 7.48-7.50 м удалось обнаружить только спикулы губок. На глубине 7.38-7.40 м содержание диатомей предельно мало; единично были отмечены отдельные обломки створок морских и пресноводных видов, а также спикулы губок. В целом, эти образцы можно считать немыми. Выше по разрезу численность диатомей незначительно возросла, выявлено присутствие морского сублиторального вида Rhabdonema minutum Kütz., а также пресноводного Aulacoseira alpigena (Grun.) Kramm. Вероятно, этот период соответствует формированию отложений в условиях приледникового водоема, где сказывалось влияние морских вод, о чем свидетельствует плохая сохранность створок диатомей и присутствие в осадках морских видов наряду с пресноводными.

Зона II (интервал 7.10-7.38 м) соответствует, преимущественно, морскому седиментогенезу. В составе диатомовых ассоциации по численности преобладают северобореальные сублиторальные виды: Paralia sulcata (Ehrb.) Cleve, Hyalodiscus scoticus (Kütz.) Grun, Rhabdonema minutum, Cocconeis scutellum, виды рода Diploneis (особенно характерные для песчаных отложений), Achnanthes brevipes и другие широко распространенные в опресненной литорали современных морей виды. В группе олигаголобов представлены Aulacoseira alpigena (Grunow) Krammer, Cyclotella stelligera (Cleve \& Grunow) Van Heurck, Cyclotella rossii Håkansson. Единичное присутствие в отложениях этой зоны створок пресноводных диатомей указывает на некоторую гидрологическую связь исследуемого водного объекта с пресными водоемами. В данной зоне сумма солоноватоводных и морских видов составляет более 90 \%, из них полигалобы - 6.7-82.2 \%; мезаголобы - 2.2-55 \%; олигогалобы - 5-79.8 \%. Доля морских видов максимальна в интервале ДО 7.28-7.30 м (82.2 \%), выше по разрезу наблюдается их уменьшение и увеличение солоноватоводных видов, доля которых в интервале 7.18-7.20 м соответствует $54.9 \%$. Концентрации створок диатомей увеличивается вверх по разрезу от 13.6 тыс. ств./г до 6.6 млн.ств./г. Видовое богатство невелико, и увеличивается от нижних слоев к верхним от 8 до 34 видов в образце. Основу диатомовых ассоциаций составляют бентосные виды (33.4-64 \%), космополиты (43-93 \%). Увеличение доли бореальных и планктонно-бентосных форм отмечается в 
интервале ДО 7.18-7.20 м за счет значимого роста обилия Paralia sulcata (60 \%). Этот вид является сублиторальным, тихопелагическим; населяет шельфовую зону морей, толерантен к абиотическим фактором среды, и служит маркером смены условий в экосистеме. Рост численности Paralia sulcata указывает на процессы распреснения морских вод [9].

Зона III (интервал 6.98-7.10 м). Интервал ДО 7.08-7.10 м составлен осадками переходной зоны от морских к озерным условиям седиментации. На этом этапе развития водоема происходит резкая смена видового состава и структуры диатомовых комплексов. Исчезают типичные морские планктонные диатомеи - Hyalodiscus scoticus, резко уменьшается доля мезогалобных видов (Paralia sulcata, Rhabdonema minutum) наряду с увеличением численности пресноводных до 80 \% (Aulacoseira alpigena; Aulacoseira pfaffiana (Reinsch) Kramm.; Cyclotella stelligera; C. rossii). Значительно увеличивается доля планктонных форм (41\%), что свидетельствует об увеличении водности водоема. Основную часть диатомовых ассоциаций составляют виды-космополиты $65 \%$, доля бореальных видов уменьшается по сравнению с предыдущим интервалом ДО до $12.3 \%$, содержание арктоальпийских видов $-1.7 \%$. Для этой зоны характерны резкое увеличение концентрации диатомей в отложениях до 131.8 млн. ств./г, видовое богатство диатомей максимальное для разреза, но в целом невысоко, 55 видов в образце. Отмечено появление цист хризофитовых водорослей, которые являются, в основном, пресноводными организмами. В ДО с глубины 7.03-7.05 м концентрация диатомей выше, чем в предыдущем интервале ДО, 174.6 млн. ств./г, но меньше их видовое богатство. В образце обнаружено 36 видов. Полностью исчезли из состава диатомовых комплексов морские и мезогалобные формы, началось формирование пресноводных отложений. Основу диатомовых ассоциаций составляют планктонные виды (59 \%). Доля бентосных форм минимальная для разреза (14 \%). В этом интервале ДО отмечается максимальное для разреза содержание галобионтов (42 \%). Согласно результатам радиоуглеродного датирования отложений этого интервала, отвечающих озерному осадконакоплению, соответствуют середине атлантического периода голоцена $\left(6170 \pm 130 \mathrm{C}^{14}\right.$ лет, или $7060 \pm 160$ календарных лет). Выше по разрезу (глубина 6.98-7.00 м) продолжает увеличиваться доля планктонный диатомей (63.2\%), что указывает на увеличение объема воды и глубины озера в этот период по сравнению с предыдущими этапами. По отношению к солености доминирует группа индифферентов (65.8 \%). Отмечено уменьшение доли галобионтов до $21 \%$, и увеличение доли галлофилов до 11.8 \%. Концентрация диатомей и видовое обилие снижаются по сравнению с ниже лежащим интервалом ДО и соответствуют 109.1 млн.ств./г и 23 видам в образце.

Зона IV (интервал 6.57-6.90 м). Продолжается развитие пресноводного водоема. Диатомовые комплексы этой зоны составлены, преимущественно типичными пресноводными планктонными центрическим таксонами родов Aulacoseira и Cyclotella, характерных для субарктических озер с низким уровнем минерализации. Вверх по разрезу отмечается уменьшение доли планктонных диатомей до 46.4\%, увеличение бентосных форм до $35 \%$, среди которых преобладают Frustulia rhomboides (Ehrenberg) De Toni, представители родов Eunotia и Brachysira. По отношению к рН среды преобладают индифференты (46-53 \%), доля алкалифилов изменяется в диапазоне от 19 \% до 34 \%. В интервале ДО 6.57-6.60 м возрастает доля ацидофилов (до $26.2 \%$ ). Это свидетельствует об уменьшении глубины водоема, зарастании его берегов и некотором заболачивании. По отношению к географической приуроченности преобладают космополиты, бореальных видов становится меньше (2.4\%), а арктоальпийских - больше (9.5\%). В данной диатомовой зоне отмечается снижение концентрации створок до 62.4 млн. ств./г. Видовое богатство низкое, 40 видов в образце.

\section{Заключение}

Установлено, что стратифицированная толща ДО из озерной котловины формировалась в позднеледниковье - голоцене, образование пресноводного водоема произошло в конце атлантического периода в результате отделения от моря. При формировании пресноводных осадков условия развития диатомовой флоры не были стабильны. 


\section{Литература}

1. Баринова С. С., Медведева Л. А., Анисимова О. В. Биоразнообразие водорослей-индикаторов окружающей среды. Тель-Авив: Piles Studio. 2006. 498 с.

2. Диатомовый анализ. Л.: 1949. Кн. 1. 240 с.; Кн. 2. 238 с.

3. Диатомовый анализ: Определитель ископаемых и современных диатомовых водорослей. Л.: Госгеолиздат. 1949. Кн. 2. 238 с.; 1950. Кн. 3.398 с.

4. Диатомовые водоросли СССР (ископаемые и современные). Л.: Наука. 1974. Т. 1. 404 с.

5. Давыдова Н.Н. Диатомовые водоросли - индикаторы природных условий водоемов в голоцене. Л.: Наука. 1985. 244 с.

6. Демодова С.В. Диатомовая флора муравинского межледниковья Беларуси. Минск: Экономпресс. 2013. 199 c.

7. Каган Л.Я. Диатомовые водоросли евро-арктического региона Аннотированная коллекция (древние и современные морские и пресноводные). Апатиты. Изд-во КНЦ РАН. 2012. 209 с.

8. Косова А.Л., Малышева М.Б., Денисов Д.Б. К методике камеральной обработки проб для диатомового анализа донных отложений // Квартер во всем его многообразии. Фундаментальные проблемы, итоги изучения и основные направления дальнейших исследований: Матер. VII Всероссийского совещания по изучению четвертичного периода (г. Апатиты, 12-17 сентября, 2011 г.). В 2 т. / Рос. Акад. Наук, Отд. наук о Земле, Комиссия по изуч. четвертич. периода, Геологический ин-т КНЦ РАН. Апатиты; СПб, 2011. Т. 1. (А-К). С. 294-295.

9. Обрезкова М.С., Колесник А.Н., Семилетов И.П. Особенности распределения диатомей в поверхностных осадках морей Восточной Арктики России (на основе кластерного анализа) // Биология моря. 2014. T. 40. № 5. C. 473-480.

10. An Atlas of British Diatoms / Ed. P. A. Sims. Bristol. 1996. 602 p.

11. Krammer K., Lange-Bertalot H. Bacillariophyceae, Subwasserflora von Mitteleuropa, V. 2 (1-4). Gustav Fisher Verlag, Stuttgart/Jena, 1988-1991.

12. Krammer K. The genus Pinnularia. In: H. Lange-Bertalot (ed.), Diatoms of Europe. 1: A.R.G. Gantner Verlag K.G. Vaduz. 2000. 703 p.

13. Krammer K. Cymbella. In: H. Lange-Bertalot (ed.), Diatoms of Europe. 3: A.R.G. GantnerVerlag K.G., Ruggell. 2002. 584 p.

14. Krammer K. Cymbopleura, Delicata, Navicymbula, Gomphocymbellopsis, Afrocymbella. In: H. Lange-Bertalot (ed.), Diatoms of Europe, 4: A.R.G. Gantner Verlag K.G. Ruggell. 2003. 530 p. 